\title{
A RANDOMIZED, DOUBLE BLIND, CONTROLLED STUDY ON THE EFFECTS OF ADDITION OF CLONIDINE TO BUPIVACAINE USED FOR PATIENTS UNDERGOING SPINAL ANAESTHESIA
}

\author{
*Bhavini Shah ${ }^{1}$, Ramchandra Shidhaye ${ }^{1}$, Devdas Divekar ${ }^{1}$, Mrudul Panditrao $^{2}$; Minnu Panditrao ${ }^{2}$; \\ Chhaya Suryawanshi ${ }^{2}$ \\ Assistant Lecturer, Professor, Department of Anesthesiology and Critical Care, Pravara Institute of \\ Medical Sciences, Loni 413736 India $^{1}$; Professor Department of Anesthesiology and Critical Care, Dr. \\ D.Y. Patil Medical College Pimpri, Pune 411018 India $^{2}$ \\ *Corresponding author: rvshidhaye@yahoo.com
}

Key words: Intrathecal; Clonidine; Bupivacaine; Postoperative pain; Spinal anaesthesia

\begin{abstract}
Background:
Spinal anaesthesia provided by bupivacaine alone may be too short for the planned surgery. The addition of clonidine $1 \mu \mathrm{g} / \mathrm{kg}$ to bupivacaine provides a prolonged anaesthetic action. The aim of this randomized double-blinded controlled study was to investigate the effects of addition of low dose clonidine to hyperbaric bupivacaine $0.5 \%$, for spinal anaesthesia in patients undergoing lower abdominal and lower limb surgeries, on analgesic efficacy, quality of block, duration of analgesia and adverse effects.
\end{abstract}

\section{Methods:}

Forty adult ASA Grade I and II patients of either sex posted for lower abdominal and lower extremity surgeries were randomly divided equally in to clonidine or control group.

Control group received intrathecal $3.5 \mathrm{ml}$ of $0.5 \%$ hyperbaric bupivacaine with $0.5 \mathrm{ml}$ of normal saline and Clonidine group received identical volume of intrathecal clonidine $1 \mu \mathrm{g} / \mathrm{kg}$ with $0.5 \%$ hyperbaric bupivacaine.

\section{Results:}

Average two level regression time (129.55 $\mathrm{min})$ was significantly prolonged in clonidine group than in the control group $(74.5 \mathrm{~min})$. (p-value $<0.01$ ) Mean time for post operative analgesia was significantly longer in clonidine group ( 8.8 hours) than in the control group (4.1 hours). (p-value < 0.01 ). Heart rate at 15 minute intervals compared to 2 minute intervals was significantly less in clonidine group. ( $\mathrm{p}$-value $<0.05$ ). Bradycardia, hypotension, urinary retention and headache did not require any therapeutic intervention

\section{Conclusion:}

Adding clonidine $1 \mu \mathrm{g} / \mathrm{kg}$ to intrathecal bupivacaine prolongs the duration of spinal anaesthesia and analgesia. It is safe and is likely to be as effective as higher doses of bupivacaine without severe adverse effects.

Spinal anaesthesia has increasingly become the technique of choice for lower abdominal and lower extremity surgeries due to quick onset and effective sensory and motor blockade and ease of administration. To overcome its disadvantage of limited duration of anaesthesia and analgesia, various adjuvant drugs (opioids, benzodiazepines, ketamine, or neostigmine) have been used which have their own side effects. In our study the $\alpha_{2}$ adrenergic agonist clonidine which has the ability 
to potentiate the effects of local anaesthetics ${ }^{1-3}$ has been used as an adjuvant. Unlike spinal opioids, clonidine does not produce pruritus or respiratory depression but prolongs the sensory blockade ${ }^{2,4}$ and reduces the amount or concentration of local anaesthetic required to produce postoperative analgesia ${ }^{5,6}$. The aim of this randomized doubleblinded controlled study was to investigate the effect of addition of clonidine to hyperbaric bupivacaine $0.5 \%$, for spinal anaesthesia in patients undergoing lower abdominal and lower limb surgeries on analgesic efficacy, quality of block, duration of analgesia and adverse effects.

\section{Materials and Methods}

After approval from the hospital ethical committee, this study was carried out in 40 adult ASA Grade I and II patients of either sex posted for lower abdominal and lower extremity surgeries. Excluding criteria were: systemic disorders like diabetes mellitus, hypertension, heart disease, allergy to bupivacaine or clonidine and all known contraindications for spinal anaesthesia, such as spine deformity, increased intracranial pressure, neurological disorders, haemorrhagic diathesis, or infection at the puncture site. A double-blind, randomized, placebo-controlled study design with two parallel groups was used. After valid informed written consent selected patients were randomly allocated to two groups by lottery method.

Clonidine group: $3.5 \mathrm{ml}$ Bupivacaine $(0.5 \%)+\mathrm{Inj}$ Clonidine $1 \mathrm{mcg} / \mathrm{kg}$ (Preservative free) + normal saline to make the volume $4 \mathrm{ml}$ intrathecally Control group: $3.5 \mathrm{ml}$ Bupivacaine $(0.5 \%)+0.5$ $\mathrm{ml}$ Normal Saline intrathecally

Both the patient and anesthesiologist were blinded to the study solutions. Syringes were prepared immediately before the spinal injection ensuring the volumes at $4 \mathrm{ml}$ by a third person other than the anaesthesiologist who administered the drugs intrathecally and later on did the parameter assessment. This third person only did the random allocation and he knew the status of experiment/control of the patient to unblind the status in case of an emergency. Sedatives and hypnotics were avoided during the pre operative and intra operative period. Intravenous line was secured with a $20 \mathrm{G}$ cannula and all patients were preloaded with Ringer Lactate solution at $10 \mathrm{ml} / \mathrm{kg}$. Lumbar puncture was done in the sitting position under aseptic conditions in the L3-L4 space with a 26G Quincke needle. Intrathecal study drug was injected and patient was placed in the supine position. The time at which the intrathecal injection was completed was considered as zero. Noninvasive arterial blood pressure, heart rate, and oxygen saturation assessed at zero time and every 2 minutes for the first 10 minutes after spinal injection, and thereafter, every 5 minutes during the surgery.

The level of sensory blockade was tested by pinprick method in midline and the motor blockade was tested with the modified Bromage scale used by Breen et al ${ }^{7}$. The time of onset and time of peak sensory and motor block, time to regression of sensory block by two dermatomes, time to full recovery of motor block, level of intra operative sedation and time to first rescue analgesic were recorded. Hypotension, defined as a decrease of systolic blood pressure of more than $20 \%$ from baseline, was treated with metaraminol and bradycardia, defined as a heart rate decrease of more than $20 \%$ from baseline was treated with atropine. For rescue analgesia Inj tramadol 100mg or Inj diclofenac sodium $75 \mathrm{mg}$ was given.

The various data obtained, which included different parameters measured at different time intervals, were calculated and compared with baseline values within each group as well as with corresponding times among groups using independent $t$ test. For comparison of complications in the two groups $\mathrm{chi}^{2}$ test was used. A 'p' value $<0.05$ was taken as significant. The sample size was not calculated before the start of the study and number of patients to be studied in the trial was based on previous literature. ${ }^{4,8}$ Post-hoc power analysis was carried out for "two segment regression time in minutes" and "time for first rescue analgesia in hours." Estimated power for two-sample comparison of means was 1.00.

\section{Results}

The patients' characteristics are shown in Table I. There is no significant difference in the two groups. (p-value $>0.05$ ) 
Table I: Demographic characteristics

\begin{tabular}{|l|l|l|}
\hline Parameter & $\begin{array}{l}\text { Clonidine group } \\
(\mathrm{n}=20) \\
\text { Mean } \pm \mathrm{SD}\end{array}$ & $\begin{array}{l}\text { Control } \\
\text { group }(\mathrm{n}=20) \\
\text { Mean } \pm \mathrm{SD}\end{array}$ \\
\hline Age (yrs) & $38.15 \pm 12.89$ & $38.2 \pm 11.00^{*}$ \\
\hline Weight $(\mathrm{kg})$ & $54.3 \pm 8.81$ & $56.85 \pm 7.12^{*}$ \\
\hline Sex (M:F) & $10: 10$ & $7: 13$ \\
\hline ASA I: II & $17: 3$ & $17: 3$ \\
\hline * p-value $>\mathbf{0 . 0 5} * *$ p-value significant at \\
0.05; $* * *$ p-value significant at 0.01
\end{tabular}

Table II compares the time for onset and peak of sensory and motor blockade in both groups. Time required for onset of sensory and motor blockade was similar in both groups. Peak sensory blockade was delayed in clonidine group than control group, but the time required for peak motor blockade was similar in both groups. Average two level regression time (129.55 $\mathrm{min})$ was significantly prolonged in clonidine group than control group (74.5 min). (p-value < 0.01)

Mean time for post operative analgesia was significantly longer in clonidine group ( 8.8 hours) than control group (4.1hour)(p-value $<0.01$ )

Table II: Analysis of Sensory, Motor blockade and Duration of analgesia

\begin{tabular}{|l|l|l|}
\hline Parameter & $\begin{array}{l}\text { Clonidine } \\
\text { group }(\mathrm{n}=20) \\
\text { Mean } \pm \mathrm{SD}\end{array}$ & $\begin{array}{l}\text { Control group } \\
(\mathrm{n}=20) \\
\text { Mean } \pm \mathrm{SD}\end{array}$ \\
\hline $\begin{array}{l}\text { Time in seconds for } \\
\text { onset of sensory } \\
\text { blockade }\end{array}$ & $70.35 \pm 16.56$ & $71.05 \pm 16.85^{*}$ \\
\hline $\begin{array}{l}\text { Time in seconds for } \\
\text { onset of motor } \\
\text { blockade }\end{array}$ & $113.7 \pm 28.16$ & $118.1 \pm 22.06^{*}$ \\
\hline $\begin{array}{l}\text { Time in minutes for } \\
\text { peak of sensory } \\
\text { blockade }\end{array}$ & $5.015 \pm 0.81$ & $4.3 \pm 0.78 * * *$ \\
\hline $\begin{array}{l}\text { Time in minutes for } \\
\text { peak of motor } \\
\text { blockade }\end{array}$ & $7.27 \pm 1.63$ & $8.25 \pm 1.91 *$ \\
\hline $\begin{array}{l}\text { Two segment } \\
\text { regression time in } \\
\text { minutes }\end{array}$ & $129.55 \pm 14.55$ & $74.5 \pm 7.16^{* * *}$ \\
\hline $\begin{array}{l}\text { Time for first rescue } \\
\text { analgesia in hours }\end{array}$ & $8.8 \pm 1.9$ & $4.1 \pm 0.6^{* * *}$ \\
\hline $\begin{array}{l}\text { p-value }>\mathbf{0 . 0 5} \\
\text { Significant at 0.05; } \\
\text { 0.01 }\end{array}$ & $* * * \mathbf{p - v a l u e ~ s i g n i f i c a n t ~ a t ~}$ \\
\hline
\end{tabular}

Table III compares heart rates, systolic and diastolic blood pressure in both groups at different time intervals. Both groups are comparable regarding systolic and diastolic blood pressure at all time except at sixty minutes. Heart rate at 15 minutes compared to 2 minutes is significantly less in clonidine group ( $\mathrm{p}$-value $<0.05$ ). Mean heart rate was significantly higher at the end of surgery in control group, than in clonidine group. (p-value < 0.01) It was more or less stable at lower levels throughout in the clonidine group.

Table III: Analysis of heart rate, systolic and diastolic blood pressure

\begin{tabular}{|c|c|c|c|c|c|c|c|c|}
\hline \multirow{2}{*}{\multicolumn{2}{|c|}{$\begin{array}{l}\text { Measured at } \\
\text { time interval } \\
\text { from the start } \\
\text { of intrathecal } \\
\text { block }\end{array}$}} & $\begin{array}{l}2 \\
\text { Min }\end{array}$ & $\begin{array}{l}15 \\
\text { Min }\end{array}$ & $\begin{array}{l}30 \\
\text { Min }\end{array}$ & $\begin{array}{l}45 \\
\text { Min }\end{array}$ & $\begin{array}{l}60 \\
\text { Min }\end{array}$ & $\begin{array}{l}90 \\
\text { Min }\end{array}$ & $\begin{array}{l}120 \\
\text { Min }\end{array}$ \\
\hline & & $\begin{array}{l}\text { Mea } \\
\mathrm{n} \pm\end{array}$ & $\begin{array}{l}\text { Mea } \\
\mathrm{n} \pm \\
\mathrm{S} n\end{array}$ & $\begin{array}{l}\text { Mea } \\
\mathrm{n} \pm\end{array}$ & $\begin{array}{l}\text { Mea } \\
\mathrm{n} \pm\end{array}$ & Mean & $\begin{array}{l}\text { Mea } \\
\mathrm{n} \pm\end{array}$ & $\begin{array}{l}\text { Mea } \\
\mathrm{n} \pm\end{array}$ \\
\hline \multirow[t]{2}{*}{$\begin{array}{l}\text { Heart } \\
\text { Rate } \\
\text { per } \\
\text { min. }\end{array}$} & $\begin{array}{l}\text { Clon } \\
\text { idine } \\
\text { grou } \\
p\end{array}$ & $\begin{array}{l}82.8 \\
\pm \\
12.4 \\
4 \\
\end{array}$ & $\begin{array}{l}76.1 \\
5 \pm \\
12.1 \\
3^{* *}\end{array}$ & $\begin{array}{l}75.8 \\
5 \pm \\
15.9 \\
3\end{array}$ & $\begin{array}{l}72.6 \\
\pm \\
12.4 \\
8\end{array}$ & $\begin{array}{l}74.32 \\
\pm 12.7 \\
6\end{array}$ & $\begin{array}{l}75.1 \\
8 \pm \\
12.1 \\
8\end{array}$ & $\begin{array}{l}71.8 \\
\pm \\
5.31\end{array}$ \\
\hline & $\begin{array}{l}\text { Cont } \\
\text { rol } \\
\text { grou } \\
p\end{array}$ & $\begin{array}{l}86.5 \\
5 \pm \\
10.0 \\
1^{*}\end{array}$ & $\begin{array}{l}82.8 \\
5 \pm \\
15.9 \\
3^{*}\end{array}$ & $\begin{array}{l}76.6 \\
\pm \\
13.1 \\
9^{*}\end{array}$ & $\begin{array}{l}71.4 \\
5 \pm \\
12.3 \\
6^{* *}\end{array}$ & $\begin{array}{l}78.17 \\
* * * \\
\pm \\
12.94\end{array}$ & $\begin{array}{l}77.0 \\
5 \pm \\
8.92 \\
* *\end{array}$ & $\begin{array}{l}78 \pm \\
6.78 \\
* * *\end{array}$ \\
\hline \multirow[t]{2}{*}{$\begin{array}{l}\text { Sys. } \\
\text { Blood } \\
\text { Pres. } \\
\mathrm{mm} \\
\text { of } \mathrm{Hg}\end{array}$} & $\begin{array}{l}\text { Clon } \\
\text { idine } \\
\text { grou } \\
\mathrm{p}\end{array}$ & $\begin{array}{l}122 . \\
65 \pm \\
13.7\end{array}$ & $\begin{array}{l}109 \\
5 \pm \\
13.5 \\
1\end{array}$ & $\begin{array}{l}106 . \\
95 \pm \\
13.4 \\
6\end{array}$ & $\begin{array}{l}100 \\
35 \pm \\
13.2\end{array}$ & $\begin{array}{l}100.6 \\
3 \\
\pm 13.8 \\
3\end{array}$ & $\begin{array}{l}107 \\
.82 \\
\pm \\
12.1 \\
6\end{array}$ & $\begin{array}{l}101 . \\
94 \\
\pm 14 . \\
00\end{array}$ \\
\hline & $\begin{array}{l}\text { Cont } \\
\text { rol } \\
\text { grou } \\
p\end{array}$ & $\begin{array}{l}117 . \\
9 \\
\pm \\
16.3 \\
9^{*}\end{array}$ & $\begin{array}{l}105 \\
65 \pm \\
13.4 \\
1^{*}\end{array}$ & $\begin{array}{l}105 . \\
05 \pm \\
14.2 \\
0^{*}\end{array}$ & $\begin{array}{l}107 \\
\pm \\
14.0 \\
3^{*}\end{array}$ & $\begin{array}{l}109.7 \\
8 \\
\pm \\
12.94 \\
* * *\end{array}$ & $\begin{array}{l}115 . \\
87 \pm \\
10.9 \\
9^{*}\end{array}$ & $\begin{array}{l}115 . \\
5 \\
\pm \\
18.2 \\
8^{*}\end{array}$ \\
\hline \multirow[t]{2}{*}{$\begin{array}{l}\text { Diast. } \\
\text { Blood } \\
\text { Pres. } \\
\mathrm{mm} \\
\text { of } \mathrm{Hg}\end{array}$} & $\begin{array}{l}\text { Clon } \\
\text { idine } \\
\text { grou } \\
p\end{array}$ & $\begin{array}{l}73.2 \\
5 \pm \\
8.6\end{array}$ & $\begin{array}{l}65.2 \\
8 \pm \\
7.99\end{array}$ & $\begin{array}{l}64.5 \\
5 \pm \\
12.3 \\
3\end{array}$ & $\begin{array}{l}61.3 \\
\pm \\
11.7\end{array}$ & $\begin{array}{l}63.12 \\
\pm 13.0 \\
2\end{array}$ & $\begin{array}{l}65.8 \\
8 \pm \\
12.4 \\
4 \\
\end{array}$ & $\begin{array}{l}58.4 \\
\pm \\
7.7\end{array}$ \\
\hline & $\begin{array}{l}\text { Cont } \\
\text { rol } \\
\text { grou } \\
p\end{array}$ & $\begin{array}{l}70.0 \\
5 \\
\pm \\
14.8 \\
*\end{array}$ & $\begin{array}{l}60.9 \\
5 \\
\pm \\
11.1 \\
4^{*}\end{array}$ & $\begin{array}{l}62.5 \\
\pm \\
12.4 \\
2^{*}\end{array}$ & $\begin{array}{l}65.1 \\
\pm \\
9.46^{*}\end{array}$ & $\begin{array}{l}67.33 \\
\pm \\
7.45^{*}\end{array}$ & $\begin{array}{l}71.4 \\
7 \pm \\
9.07 \\
*\end{array}$ & $\begin{array}{l}72.5 \\
\pm \\
9.57 \\
*\end{array}$ \\
\hline \multicolumn{4}{|c|}{$\begin{array}{l}* \text { p-value }>0.05 \\
\text { significant at } 0.05 \\
0.01\end{array}$} & \multicolumn{5}{|c|}{$\begin{array}{l}* * \text { p-value } \\
\text { gnificant at }\end{array}$} \\
\hline
\end{tabular}

Table IV shows the incidence of complications in both groups which were not serious enough to warrant any intervention. There was no morbidity. 
Table IV: Complications

\begin{tabular}{|l|l|l|}
\hline Complications & $\begin{array}{l}\text { Clonidine Group } \\
(\mathrm{n}=20)\end{array}$ & $\begin{array}{l}\text { Control Group } \\
(\mathrm{n}=20)\end{array}$ \\
\hline Bradycardia & $\begin{array}{l}\# \\
5(25 \%)\end{array}$ & $3(15 \%)$ \\
\hline Hypotension & $4(20 \%)$ & $2(10 \%)$ \\
\hline Urinary Retention & $2(10 \%)$ & $0(0 \%)$ \\
\hline $\begin{array}{l}\text { Position-dependent } \\
\text { headache }\end{array}$ & 0 & 0 \\
\hline $\begin{array}{l}\# \text { data are number of cases and percentage of } \\
\text { total. }\end{array}$
\end{tabular}

There was no significant difference between the groups. (p-value $>0.05$ )

Patients from clonidine group were found to be more sedated but respiratory depression was not observed.

Respiratory rate and oxygen saturation $\left(\mathrm{SpO}_{2}\right)$ were similar in both groups.

\section{Discussion}

Clonidine is now an acceptable adjuvant to local anaesthetics for epidural route $^{1}$; nevertheless clinical trials provide evidence that less clonidine is needed intrathecally than epidurally to produce the same analgesic effect with fewer side effects ${ }^{2}$. Hypotension was less pronounced after intrathecal than oral clonidine ${ }^{3}$. Intrathecal clonidine has been used to enhance postoperative analgesia in cesarean deliveries, repair of femoral fractures, and ambulatory knee arthroscopy ${ }^{2-6}$. According to Niemi $L^{7}$ marked haemodynamic changes and sedation, limits the usefulness of intrathecal clonidine. He used very high doses $(3 \mu \mathrm{g} / \mathrm{kg})$ of clonidine. van Tuijl I et al ${ }^{8}$ used very low doses of intrathecal Clonidine $(15 \mu \mathrm{g})$ with satisfactory outcome. Their patients were for inguinal herniorrhaphy and knee arthroscopy. We included lower abdominal surgeries in our study and so we decided to use low dose $(1 \mu \mathrm{g} / \mathrm{kg})$ similar to Kaabachi $\mathrm{O}$ et al ${ }^{9}$. Time required for onset of sensory and motor blockade and peak motor blockade was found to be similar in both groups in our study. Though peak sensory blockade was found to be delayed in clonidine group it has very little clinical significance. Similar to many other studies ${ }^{9,10} \mathrm{We}$ also found that addition of $1 \mu \mathrm{g} / \mathrm{kg}$ of clonidine to $0.5 \%$ bupivacaine significantly prolongs the block (average two level regression time, clonidine $:$ control $=129.55: 74.5 \mathrm{~min}$ ) and postoperative analgesia ( 8 to $10 \mathrm{hrs}$ ) and thus reduces the postoperative analgesic requirement.
De Negri P et al ${ }^{11}$ observed minimal influence on haemodynamic parameters with 105 micrograms of intrathecal Clonidine. We also found both groups comparable with regard to systolic and diastolic blood pressure at almost all time intervals. Though heart rates started dropping in Clonidine group after 15 minutes, maximum being after 45 minutes, bradycardia was never severe to be a cause for concern. In conclusion, the present study indicates that adding clonidine $1 \mu \mathrm{g} / \mathrm{kg}$ to intrathecal bupivacaine prolongs spinal anaesthesia and the duration of analgesia. It is safe and is as effective as bupivacaine in higher dosage without severe adverse effects.

\section{References}

1. Persec, J., Z. Persec, and I. Husedzinovic, Postoperative pain and systemic inflammatory stress response after preoperative analgesia with clonidine or levobupivacaine: a randomized controlled trial. Wien Klin Wochenschr, 2009. 121(17-18):558-63.

2. Filos KS, G.L., Patroni O, Polyzou V., Intrathecal clonidine as a sole analgesic for pain relief after cesarean section. Anesthesiology. 1992 ;77(2):26774.

3. Dobrydnjov I, A.K., Samarütel J, Holmström B., Postoperative pain relief following intrathecal bupivacaine combined with intrathecal or oral clonidine. Acta Anaesthesiol Scand. 2002 ;46(7):806-14.

4. De Kock, M., et al., Intrathecal ropivacaine and clonidine for ambulatory knee arthroscopy: a doseresponse study. Anesthesiology, 2001. 94(4):574-8.

5. Elia N, C.X., Mazza C, Schiffer E, Tramèr MR., Clonidine as an adjuvant to intrathecal local anesthetics for surgery: systematic review of randomized trials.

Reg Anesth Pain Med. 2008;33(2):159-67.

6. van Tuijl I, van der Werff DB, Kalkman CJ., The effect of addition of intrathecal clonidine to hyperbaric bupivacaine on postoperative pain and morphine requirements after Caesarean section: a randomized controlled trial. Br J Anaesth. 2006; 97(3):365-70.

7. Niemi L, Effects of intrathecal clonidine on duration of bupivacaine spinal anaesthesia, haemodynamics, and postoperative analgesia in patients undergoing knee arthroscopy. Acta Anaesthesiol Scand. 1994 ;38(7):724-8.

8. van Tuijl, I., et al., Intrathecal low-dose hyperbaric bupivacaine-clonidine combination in outpatient knee arthroscopy: a randomized controlled trial. Acta Anaesthesiol Scand, 2008. 52(3):343-9. 
9. Kaabachi O, Z.A., Ouezini R, Abdelaziz AB, Chattaoui O, Kokki H., Clonidine $1 \mathrm{microg} / \mathrm{kg}$ is a safe and effective adjuvant to plain bupivacaine in spinal anaesthesia in adolescents. Anesth Analg. 2007;105(2):516-9.

10. Santiveri, X.A., A.; Plaja, I.; Metje, M. T.; Martínez, B.; Villalonga, A.; López, M., Anaesthetic and postoperative analgesic effects of spinal clonidine as an additive to prilocaine in the transurethral resection of urinary bladder tumours.

European Journal of Anaesthesiology: 2002 ;19: 589-593.

11. De Negri P, B.F., Salvatore R, Visconti C, De Vivo $\mathrm{P}$, Mastronardi $\mathrm{P}$, Spinal anaesthesia with clonidine and bupivacaine in young humans: interactions and effects on the cardiovascular system. Minerva Anestesiol. 1997;63(4):119-25.

$* * * * * * * * * * * * * * * * * * * * * * * * * * * * * * * * * * * * * * * * * * * * * * * * * * * * * * * * * * * *$

THE COLLEGE OF ANAESTHESIOLOGISTS OF SRI LANKA

LECTURE DEMONSTRATION \& CERTIFICATION

ON

\author{
Cardio Pulmonary Resuscitation \\ Venue - $\quad$ Trauma Lecture Hall \\ National Hospital, Sri Lanka \\ Date $\quad$ - on Tuesdays \\ Time $\quad$ - $9.00 \mathrm{am}$ \\ Conducted by \\ Dr Shirani Hapuarachchi \\ Consultant Anaesthetist, NSU \\ Contact \\ Ms Chamila Gamage, \\ Office Secretary, 2672327/2691111-Ext 2571
}

